\title{
TRACER STUDY: THE ALIGNMENT OF WORK TYPES WITH THE ORIGIN OF ALUMNI SPECIALIZATION OF FKM UI
}

\author{
Rina Efiyanna ${ }^{1}$, Sutanto Priyo Hastono ${ }^{1}$, Ahmad Syafiq ${ }^{2}$ \\ ${ }^{1}$ Departemen Biostatistik dan Kependudukan Fakultas Kesehatan Masyarakat Universitas \\ Indonesia \\ ${ }^{2}$ Departemen Gizi Masyarakat Fakultas Kesehatan Masyarakat Universitas Indonesia \\ E-mail: rinagzy@yahoo.com
}

Submited: 8 October 2018 ; Accepted: 10 October 2019

https://doi.org/10.36525/sanitas.2019.3

\begin{abstract}
The purpose of the study is to find out the alignment of the work types with the original specialization of alumni from the public health faculty of Universitas Indonesia based on the results of 2010-2017 tracer study of public health undergraduate of FKM UI. The study used secondary data from the 2010-2017 FKM UI Tracer Study with samples 298 people. Moreover, the study used Multivariate Analysis, especially multiple logistic regression analysis. The results of the multivariate analysis showed that the variables were significantly related to work alignment, namely variables of the origin specialization and the number of applying for jobs. Then, the variables of residency, work waiting period, additional courses and the number of interview calls are called confounding variables. The analysis results of Odds Ratio (OR) from the original specialization variables are 3. It means 3 alumni whose original specialization in Occupational Safety Health (K3) will get job which is line with their specialization 3 times higher than alumni whose specialization in Science Public Health (IKM) after getting controlled variables, such as the number of job applications, residency, work waiting period, additional courses and number of interview calls.
\end{abstract}

Keywords: graduates, origin of specialization, Tracer Study

\section{TRACER STUDY: KESELARASAN JENIS PEKERJAAN DENGAN ASAL PEMINATAN ALUMNI FKM UI}

\begin{abstract}
ABSTRAK
Tujuan penelitian ini adalah untuk mengetahui mengenai keselarasan jenis pekerjaan dengan asal peminatan alumni fakultas kesehatan masyarakat Universitas Indonesia berdasarkan hasil tracer study sarjana kesehatan masyarakat FKM UI tahun 2010- 2017. Penelitian ini menggunakan data sekunder dari hasil tracer study FKM UI tahun 2010 -2017 dengan sampel sebanyak 298 orang. Analisis Multivariat yang digunakan yaitu Analisis Regresi Logistik Ganda. Hasil analisis multivariat menunjukkan bahwa variabel yang berhubungan bermakna dengan keselarasan pekerjaan yaitu variabel asal peminatan dan jumlah melamar pekerjaan. Sedangkan variabel tempat tinggal,masa tunggu kerja,kursus tambahan dan jumlah panggilan wawancara merupakan variabel confounding. Hasil analisis didapatkan Odds Ratio (OR) dari variabel asal peminatan (3) adalah 3 artinya alumni yang asal peminatan pada saat perkuliahannya Kesehatan Keselamatan Kerja (K3) akan mendapatkan pekerjaan yang selaras dengan peminatannya sebesar 3 kali lebih tinggi dibandingkan dengan alumni yang asal peminatannya Ilmu Kesehatan Masyarakat (IKM) setelah dikontrol variabel jumlah lamaran, tempat tinggal, masa tunggu kerja, kursus tambahan dan jumlah panggilan wawancara.
\end{abstract}

Kata Kunci: Tracer study, keselarasan pekerjaan, asal peminatan 


\section{PENDAHULUAN}

Salah satu cara untuk menggali informasi berkaitan dengan transisi dari kuliah ke pekerjaan adalah dengan melaksanakan suatu studi yang biasanya disebut sebagai Tracer Study. Dengan kata lain, Tracer Study adalah Studi mengenai lulusan Lembaga penyelenggara Pendidikan tinggi(1). Istilah lain dari tracer study yang sering digunakan adalah "Graduate Surveys" dan "Alumni Researches"(2). Peran serta alumni serta sumbangsih dalam masyarakat dan pembangunan di bidang kesehatan merupakan salah satu indikator penting dalam keberhasilan Pendidikan tinggi. Implementasi tracer study di tingkat perguruan tinggi merupakan karakteristik penting yang menjadi ciri kemajuan institusi pendidikan tinggi di negara-negara maju. Tracer Study dapat menyediakan informasi untuk kepentingan evaluasi hasil Pendidikan tinggi dan selanjutnya dapat digunakan untuk penyempurnaan dan penjaminan kualitas lembaga pendidikan tinggi bersangkutan(3). Oleh sebab itu, pada penilaian akreditasi institusi perguruan tinggi pada borang akreditasi standar 3 (tiga) B terdapat penilaian yang berkaitan dengan tracer study.

Fakultas Kesehatan Masyarakat Universitas Indonesia (FKM UI) sebagai institusi Pendidikan tinggi telah mencetak sumber daya manusia (SDM) Sarjana dan Pasca Sarjana yang cukup banyak dalam bidang kesehatan masyarakat dalam kurun waktu periode tahun 2010-2017 yang kini telah mengaplikasikan ilmu yang didapat di FKM UI untuk di terapkan di masyarakat. FKM UI terdiri atas empat program studi yaitu Gizi, Kesehatan Lingkungan, Kesehatan Keselamatan Kerja (K3) dan Ilmu Kesehatan Masyarakat (IKM)(4). Tracer study untuk pertama kalinya sudah dilakukan di FKM UI pada tahun 2003 yang mencakup lulusan SKM regular tahun 1993 sampai tahun 2002 yang berjumlah 422 orang. Jumlah keseluruhan responden yang berhasil dilacak yaitu 262 orang $(62,1 \%)$. Tujuan utama dari kegiatan tracer study adalah untuk mengetahui atau mengidentifikasi kualitas lulusan di dunia kerja(5).

Data dari tracer study yang digunakan dalam penelitian ini adalah periode dari tahun 2010 -2017 karena pada periode ini sudah menggunakan kuesioner tracer study yang baku dan sudah terstandardisasi oleh Kementerian Pendidikan Tinggi (KEMENDIKTI). Walaupun Rumpun Kesehatan di UI memiliki banyak Fakultas namun FKM merupakan target utama dari pelaksanaan tracer study yang akan diteliti. 
Lapangan pekerjaan yang cukup terbatas mengakibatkan banyak sekali lulusan dari suatu perguruan tinggi tidak memperhatikan kesesuaian/keselarasan antara bidang peminatan yang diambil saat kuliah dengan bidang pekerjaan yang akan diambil(6). Hal ini menyebabkan peneliti ingin mengetahui terutama pada SDM di bidang kesehatan khususnya Alumni/lulusan FKM UI sebagai SDM bidang kesehatan yang mempunyai peran sangat penting dalam perkembangan kesehatan masyarakat di Indonesia. Oleh sebab itu penulis tertarik untuk melakukan penelitian yang bertujuan untuk mengetahui keselarasan pekerjaan dengan asal peminatan alumni FKM UI berdasarkan hasil tracer study sarjana kesehatan masyarakat FKM UI tahun 2010- 2017.

\section{METODE PENELITIAN}

Jenis desain penelitian ini adalah cross sectional. Penelitian ini berlokasi di Fakultas Kesehatan Masyarakat Universitas Indonesia (FKM UI) data sekunder tahun 2010-2017. Populasi target dari tracer study adalah seluruh lulusan pada kohort tahun kelulusan tertentu (di Indonesia: 2 tahun setelah lulus) dari seluruh peminatan yang ada di Fakultas Kesehatan Masyarakat UI Program studi Sarjana (S1) pada tahun 2010-2017. Pendekatan ini disebut sebagai pendekatan sensus. Dalam pendekatan sensus, responden yang mengisi kuesioner adalah hasil dari sampling alami,_bukan ditarik dari suatu kerangka sampel (sampling_frame). Penting dicatat bahwa pendekatan sensus bukan dimaksud untuk menjadikan seluruh anggota populasi target sebagai responden (response rate 100\%) tetapi lebih pada aspek sasaran populasi 100\% untuk dapat dicapai oleh survey (100\% delivered cases)(7). Pengumpulan data menggunakan kuesioner tracer study yang sudah terstandardisasi oleh Kemenristekdikti yang tertuang pada lampiran Surat Edaran Nomor: 313/B/SE/2016 tentang Pelaksanaan Tracer Study Tingkat Perguruan Tinggi. Pelaksanaan pengumpulan data dengan menggunakan kuesioner standar tersebut melalui berbagai cara misalnya surat biasa, email, wawancara tatap muka atau online. Variabel yang diukur dalam penelitian ini antara lain variabel asal peminatan, keselarasan pekerjaan, ketepatan kelulusan, sumber biaya kuliah, keanggotaan organisasi, jumlah melamar pekerjaan, tempat tinggal, masa tunggu kerja, kursus tambahan dan jumlah panggilan wawancara. Data yang digunakan yaitu data sekunder dari data tracer study FKM UI tahun 2010-2017. Hasil 
rekapitulasi jumlah subjek penelitian awalnya adalah 799 orang $_{2}$ namun setelah dilakukan cleaning data maka didapatkan 298 orang yang dapat dilakukan pengolahan data lebih lanjut. Metode analisis dan pengolahan data yang digunakan yaitu univariat, bivariat dan multivariat (analisis regresi logistik ganda). Nomor kode etik dari penelitian ini yaitu Ket 353/UN2.F10/PPM.00.02/2019 yang dikeluarkan oleh Badan Kaji etik Fakultas Kesehatan Masyarakat Universitas Indonesia.

\section{HASIL DAN PEMBAHASAN}

\section{Hasil}

Tabel 1. Karakteristik Responden (Variabel Kategorik)

\begin{tabular}{llcc}
\hline \multicolumn{1}{c}{ Karkteristik } & \multicolumn{1}{c}{ Kategori } & N & Persentase (\%) \\
\hline Asal Peminatan & Gizi & 55 & 18,5 \\
& Kesehatan Lingkungan & 27 & 9,1 \\
& Kesehatan Keselamatan Kerja (K3) & 97 & 32,6 \\
& Ilmu Kesehatan Masyarkat & 119 & 39,9 \\
Keselarasan & Selaras & 236 & 79,2 \\
Pekerjaan & Tidak selaras & 62 & 20,8 \\
Ketepatan Kelulusan & Tepat waktu & 259 & 86,9 \\
& Tidak tepat waktu & 39 & 13,1 \\
Tempat Tinggal & Kos/Asrama & 183 & 61,4 \\
& Orangtua/Keluarga & 115 & 38,6 \\
Sumber Biaya & Orang Tua/Keluarga & 216 & 72,5 \\
Kuliah & Beasiswa & 82 & 27,5 \\
Keanggotaan & Ya & 273 & 91,6 \\
Organisasi & Tidak & 25 & 8,4 \\
Kursus Tambahan & Ya & 62 & 20,8 \\
& Tidak & 236 & 79,2 \\
\hline
\end{tabular}

Tabel 2. Karakteristik Responden (Variabel Numerik)

\begin{tabular}{lccccc}
\hline Karakteristik & Mean & Median & Min-Max & SD & CI 95 \% \\
\hline Masa Tunggu & 2,12 & 1 & $0-24$ & 27,3 & $1,8-2,4$ \\
Jumlah lamaran kerja & 13,2 & 7 & $1-99$ & 17,5 & $11,2-15,2$ \\
Jumlah wawancara & 5,2 & 3 & $0-75$ & 7,2 & $4,3-5,9$ \\
\hline
\end{tabular}

Gambaran Karakteristik Responden 
Dari 298 Responden, jumlah terbanyak berasal -dari peminatan ilmu kesehatan masyarakat yaitu sebanyak 119 orang $(39,9 \%)$, responden juga sebagian besar jenis pekerjaan selaras dengan bidang keilmuwan yaitu 236 orang $(79,2 \%)$, responden bertempat tinggal selama kuliah yang terbanyak yaitu dengan keluarga yaitu 183 orang $(61,4 \%)$, Sebagian besar lulus tepat waktu $(86,9 \%)$, sebagian besar biaya kuliah berasal dari orang tua/keluarga (72,5\%), Responden sebagian besar mengikuti organisasi (91,6\%), sebagian besar responden tidak mengikuti kursus tambahan $(79,2 \%)$, rata-rata masa tunggu kerja selama 2 bulan,_rata-rata jumlah melamar kerja yaitu 13 dan rata-rata panggilan wawancara yaitu sebanyak 5 kali.

Tabel 3. Model Akhir Analisis Regresi Logistik Ganda

\begin{tabular}{lcccccccc}
\hline & B & SE & Wald & Df & Sig & Exp(B) & \multicolumn{2}{c}{ 95 \% CI for Exp (B) } \\
\cline { 8 - 9 } & & & & & & & \multicolumn{3}{c}{ Lower } & Upper \\
\hline Asal Peminatan & & & 27.718 & 3 & .001 & & & .129 \\
Asal Peminatan (1) & $-1,322$ & 0,370 & 12.735 & 1 & .001 & .267 & .551 \\
Asal Peminatan (2) & $-0,093$ & 0,542 & .029 & 1 & .864 & .912 & .315 & 2.637 \\
Asal Peminatan (3) & 1,107 & 0,461 & 5.763 & 1 & .016 & 3.024 & 1.225 & 7.465 \\
Tempat Tinggal & 0,609 & 0,329 & 3.422 & 1 & .064 & 1.838 & .964 & 3.504 \\
Kursus Tambahan & 0,555 & 0,368 & 2.274 & 1 & .132 & 1.743 & .847 & 3.586 \\
Masa Tunggu & $-0,057$ & 0,051 & 1.286 & 1 & .257 & .944 & .855 & 1.043 \\
Jumlah lamaran kerja & $-0,027$ & 0,012 & 4.859 & 1 & .028 & .974 & .951 & .997 \\
Wawancara Pekerjaan & 0,088 & 0,049 & 3.285 & 1 & .070 & 1.092 & .993 & 1.202 \\
Constant & 0,131 & 0,775 & .029 & 1 & .866 & 1.140 & & \\
\hline
\end{tabular}

Hubungan keselarasan pekerjaan dengan asal peminatan alumni FKM UI

Dari hasil analisis multivariat dengan menggunakan analisis regresi logistik, Hasil analisis menunjukkan bahwa variabel yang berhubungan bermakna dengan keselarasan pekerjaan yaitu variabel asal peminatan dan jumlah lamaran kerja ( $\mathrm{p}$ value $<0,05$ ). Sedangkan variabel tempat tinggal,_masa tunggu kerja,_kursus tambahan dan jumlah panggilan wawancara merupakan variabel confounding. Hasil analisis didapatkan Odds Ratio (OR) dari variabel asal peminatan (3) adalah 3 artinya alumni yang asal peminatan pada saat perkuliahannya Kesehatan Keselamatan Kerja (K3) akan mendapatkan pekerjaan yang selaras dengan peminatannya sebesar 3 kali lebih tinggi dibandingkan dengan alumni yang asal peminatannya Ilmu Kesehatan Masyarakat (IKM) setelah dikontrol variabel jumlah 
lamaran, tempat tinggal, masa tunggu kerja, kursus tambahan dan jumlah panggilan wawancara.

\section{Pembahasan}

Berdasarkan hasil analisis multivariat dengan analisis regresi logistik ganda didapatkan bahwa asal peminatan secara signifikan berhubungan dengan keselarasan pekerjaan dengan nilai $\mathrm{p}=0,001$ dan jumlah lamaran pekerjaan dengan nilai $\mathrm{p}=0,028$. Untuk variabel tempat tinggal, masa tunggu kerja, kursus tambahan dan jumlah panggilan wawancara memang tidak secara signifikan berhubungan namun berpengaruh sangat besar terhadap variabel keselarasan pekerjaan hal ini terlihat dari perubahan nilai odds ratio-nya.

Keselarasan pekerjaan dengan asal peminatan menunjukkan hasil yang signifikan secara statistik hal ini sejalan dengan penelitian sebelumnya bahwa asal peminatan berpengaruh terhadap keselarasan pekerjaan(7). Hal ini diperkuat dari hasil penelitian ini didapatkan bahwa odds ratio (OR) dari variabel asal peminatan (3) adalah 3 artinya alumni yang asal peminatan pada saat perkuliahannya Kesehatan Keselamatan Kerja (K3) akan mendapatkan pekerjaan yang selaras dengan peminatannya sebesar 3 kali lebih tinggi dibandingkan dengan alumni yang asal peminatannya Ilmu Kesehatan Masyarakat (IKM) setelah dikontrol variabel jumlah lamaran, tempat tinggal, masa tunggu kerja, kursus tambahan dan jumlah panggilan wawancara.

Dunia kerja merupakan dunia baru bagi para lulusan dan suatu masa transisi dari perkuliahan dengan penerapan dari ilmu yang didapat. Oleh sebab itu tujuan utama dari kegiatan tracer study adalah untuk mengetahui atau mengidentifikasi kualitas lulusan di dunia kerja(8). Kualitas lulusan tidak lepas dari kualitas lembaga pendidikan dari lulusan tersebut yang merupakan factor penting bagi suatu perusahaan atau institusi yang merekrutnya sebagai pegawai(9). Akhir--akhir ini banyak sekali perusahaan yang mengeluhkan dan menyayangkan ketidakselarasan antara bidang keahlian karyawan dengan bidang pekerjaannya(10). Hal ini sejalan dengan penelitian ini yang menyatakan bahwa asal peminatan mempengaruhi keselarasan pekerjaan. 
Dinamika dan perubahan di dunia kerja semakin membutuhkan kompetensi atau softskills disamping pengetahuan teoritis-praktis-spesifik disiplin ilmu, dalam hal ini Brennan,_Kogan dan Teichler (1996) menyatakan bahwa “... higher education is becoming more and more necessary,_but less and less sufficient"(11). Keselarasan pekerjaan juga dipengaruhi oleh variabel tempat tinggal, masa tunggu kerja, kursus tambahan dan jumlah panggilan wawancara meskipun hasil statistik tidak signifikan namun variabel tersebut merupakan variabel confounding hal ini ditunjukkan dengan perubahan OR pada model > $10 \%$.

Pada variabel kursus tambahan memiliki nilai odds ratio terbesar yaitu 1,7 artinya alumni yang sewaktu kuliah mengikuti kursus tambahan akan mendapatkan pekerjaan yang selaras dengan peminatannya sebesar 1,7 kali lebih tinggi dibandingkan dengan alumni yang tidak mengikuti kursus tambahan setelah dikontrol variabel asal peminatan, jumlah lamaran,_tempat tinggal,_masa tunggu kerja dan wawancara pekerjaan.

Penelitian ini menggunakan data sekunder dari laporan Tracer Study Universitas Indonesia sehingga memiliki beberapa keterbatasan diantaranya yaitu terbatasnya variabel penelitian dan terdapat beberapa responden yang tidak menjawab pertanyaan karena di dalam pengisian kuesioner Tracer Study bersifat sukarela tidak ada kewajiban untuk mengisi keseluruhan dari kuesionernya ${ }^{7}$, sehingga peneliti berusaha mencari variabel pengganti yang relevan dengan tujuan peneitian.

\section{SIMPULAN}

Hasil dari Tracer Study merupakan alat yang cukup kuat untuk menggambarkan karakteristik dari masa transisi lulusan ke dunia kerja. Berdasarkan hasil dari uji statistik regresi logistic ganda menunjukkan bahwa asal peminatan dari Lulusan FKM UI pada jenjang sarjana regular berhubungan secara signifikan terhadap keselarasan pekerjaan dengan nilai $\mathrm{p}=0.001$. Selain itu variabel jumlah lamaran pekerjaan juga mununjukkan hubungan secara signifikan terhadap keselarasan pekerjaan dengan nilai $p=0.028$. Dari hasil penelitian ini juga didapatkan bahwa odds ratio (OR) dari variabel asal peminatan (3) adalah 3 artinya alumni yang asal peminatan pada saat perkuliahannya Kesehatan Keselamatan Kerja (K3) akan mendapatkan pekerjaan yang selaras dengan peminatannya 
sebesar 3 kali lebih tinggi dibandingkan dengan alumni yang asal peminatannya Ilmu Kesehatan Masyarakat (IKM) setelah dikontrol variabel jumlah lamaran, tempat tinggal, masa tunggu kerja, kursus tambahan dan jumlah panggilan wawancara._Variabel tempat tinggal, masa tunggu kerja, kursus tambahan dan jumlah panggilan wawancara meskipun hasil statistik tidak signifikan namun variabel tersebut merupakan variabel confounding. Hal ini ditunjukkan dengan perubahan OR pada model $>10 \%$.

\section{Saran}

Dalam pemilihan peminatan para mahasiswa sebaiknya diberi pembekalan mengenai pengetahuan transisi ke dunia pekerjaan terutama bidang pekerjaan yang akan dipilih. Karena berdasarkan hasil uji statistik penelitian ini menunjukkan bahwa asal peminatan berhubungan secara signifikan terhadap keselarasan pekerjaan. Pada masa inilah peran dari kursus tambahan juga harus menjadi perhatian karena berpengaruh terhadap keselarasan pekerjaan.

\section{DAFTAR PUSTAKA}

1. Schomburg H. A Practical Guide on Tracer Studies. Torino: European Training Foundation; 2014.

2. Gines AC. Tracer study of PNU graduates. Am Int J Contemp Res. 2014;4(3):81-98.

3. Shongwe M, Ocholla DN. A Tracer Study of LIS Graduates At the University of Zululand. Mousaion. 2011;29(2):227-45.

4. Fakultas Kesehatan Masyarakat Universitas Indonesia. Buku Panduan Pendidikan 2018. Depok: Universitas Indonesia,UI-Press; 2018.

5. Syafiq A, Fikawati S. Tracer Study: Melacak Jejak Lulusan FKM UI (Hasil Study Kualitatif Tracer Sarjana Kesehatan Masyarakat FKM UI 2006). Kesmas Natl Public Heal J. 2016;1(6):252.

6. Pontillas V V. Tracer Study on Bachelor of Science in Electrical Engineering Graduates of a Polytechnic College in the Philippines from 2007 to 2010. 2018;6(2):36-46.

7. Syafiq A, Fikawati S. Metodologi dan Manajemen Tracer Study. Depok: Direktorat Rina Efiyanna, Sutanto Priyo Hastono, Ahmad Syafiq | 33 
Pengembangan Karir dan Hubungan Alumni (PKHA) Universitas Indonesia,UI Press; 2017.

8. Zelila CZ. Pengembangan Sistem Informasi Penelusuran Lulusan (Tracer Study) pada Politeknik Kesehatan Kemenkes RI Aceh di Propinsi Aceh. Universitas Indonesia; 2013.

9. Garcia CMR, Vergara J, Lansang CJ. Graduate Tracer Study of the Bachelor of Science in Marine Transportation at the Maritime Academy of Asia and the Pacific. 2016;(0).

10. Sanchez MPR, Diamante VAM. Graduate tracer study of the college of nursing. Malaysian J Nurs. 2017;8(January):41-7.

11. Brennan J, M K, Teicler U. Higher Education and Work. London, Bristol, Pennsylvania.: Jessica Kingsley Publication; 1996. 